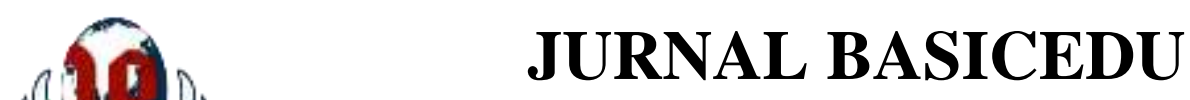

Volume 5 Nomor 5 Tahun 2021 Halaman 4160 - 4168

Research \& Learning in Elementary Education

https://jbasic.org/index.php/basicedu

PRHLAWAN

\title{
Pengaruh Breakout Room Aplikasi Zoom terhadap Kemampuan Berpikir Kritis Mahasiswa PGSD pada Perkuliahan dalam Jaringan
}

\author{
Eko Febri Syahputra Siregar ${ }^{1 凶}$, Suci Perwita Sari $^{2}$, Baihaqi Siddik Lubis ${ }^{3}$, \\ Ismail Hanif Batubara ${ }^{4}$
}

Pendidikan Guru Sekolah Dasar, Universitas Muhammadiyah Sumatera Utara, Indonesia ${ }^{1,2,3,4}$

E-mail: ekofebrisyahputra@umsu.ac.id ${ }^{1}, \underline{\text { Suciperwita@umsu.ac.id }}^{2}$, $\underline{\text { Baihaqisiddik@umsu.ac.id }}^{3}$,

Ismailhanif@umsu.ac.id ${ }^{4}$

\begin{abstract}
Abstrak
Penelitian ini bertujuan untuk mengetahui pengaruh Breakout Room Aplikasi Zoom terhadap kemampuan berpikir kritis mahasiswa PGSD pada mata kuliah Strategi Belajar Mengajar tahun akademik 2020/2021. Jenis penelitian yang digunakan yaitu pre-experimental design dengan desain penelitian the one shoot case study. Populasi penelitian yaitu mahasiswa Semester dua Program studi PGSD sebanyak 45 orang. Teknik penentuan sampel menggunakan simple random sampling dan pengumpulan data menggunakan tes dan non tes. Teknik analisa data yaitu teknik statistik deskriptif dan inferensial untuk menguji hipotesis penelitian melalui anava dua jalur, taraf signifikan 0,05 . Uji persyaratan yang dilakukan adalah uji normalitas menggunakan liliefors sedangkan uji homogenitas menggunakan uji $\mathrm{F}$ Bartlett dengan kriteria jika $\mathrm{F}_{\text {hitung }}<\mathrm{F}_{\text {tabel }}$ pada taraf signifikan $5 \%$ maka data hasil penelitian homogen. Pengujian hipotesis yaitu $\mathrm{F}_{\text {hitung }}>\mathrm{F}_{\text {tabel }}$ pada taraf signifikan $5 \%$ maka hipotesis diterima. Hasil uji one sample t test menunjukkan nilai sig. (2-tailed) $0,00<0,05$ dengan taraf signifikan sebesar $0,05 \%$ sehingga disimpulkan bahwa $\mathrm{H}_{0}$ ditolak dan $\mathrm{H}_{a}$ diterima dengan hipotesis yaitu terdapat pengaruh Breakout Room Aplikasi Zoom terhadap kemampuan berpikir kritis mahasiswa PGSD pada mata kuliah Strategi Belajar Mengajar tahun akademik 2020/2021.
\end{abstract}

Kata Kunci: Breakout Room Zoom, Kemampuan Berpikir Kritis, Perkuliahan dalam Jaringan (online).

\begin{abstract}
This study aims to determine the effect of the Zoom Application Breakout Room on the critical thinking skills of PGSD students in the Teaching and Learning Strategy course for the 2020/2021 academic year. The type of research used is preexperimental design with the one shoot case study research design. The research population is 45 students in the second semester of the PGSD study program. The technique of determining the sample using simple random sampling and collecting data using tests and non-tests. Data analysis techniques are descriptive and inferential statistical techniques to test research hypotheses through two-way ANOVA, significant level 0.05. The requirements test carried out was the normality test using liliefors while the homogeneity test used the Bartlett $F$ test with the criteria that if $F_{\text {count }}<F_{\text {table }}$ at a significant level of 5\%, the research data were homogeneous. Hypothesis testing is $F_{\text {count }}<F_{\text {table }}$ at a significant level of $5 \%$, then the hypothesis is accepted. The results of the one sample t test show the value of sig. (2-tailed) $0.00<0.05$ with a significant level of $0.05 \%$ so it can be concluded that $H_{0}$ is rejected and $H_{a}$ is accepted with the hypothesis that there is an effect of the Zoom Application Breakout Room on the critical thinking skills of PGSD students in the Teaching and Learning Strategy course. academic 2020/2021.
\end{abstract}

Keywords: Breakour Room Zoom, Critical Thinking Skills, Online Lecturers.

Copyright (c) 2021 Eko Febri Syahputra Siregar, Suci Perwita Sari, Baihaqi Siddik Lubis, Ismail Hanif Batubara

Corresponding author :

Email : ekofebrisyahputra@umsu.ac.id

DOI : https://doi.org/10.31004/basicedu.v5i5.1479

ISSN 2580-3735 (Media Cetak)

ISSN 2580-1147 (Media Online)

Jurnal Basicedu Vol 5 No 5 Tahun 2021

p-ISSN 2580-3735 e-ISSN 2580-1147 
4161 Pengaruh Breakout Room Aplikasi Zoom terhadap Kemampuan Berpikir Kritis Mahasiswa PGSD pada Perkuliahan dalam Jaringan - Eko Febri Syahputra Siregar, Suci Perwita Sari, Baihaqi Siddik Lubis, Ismail Hanif Batubara

DOI: https://doi.org/10.31004/basicedu.v5i5.1479

\section{PENDAHULUAN}

Kebijakan Pemerintah dalam menerapkan Pembatasan Sosial Berskala Besar (PSBB) memiliki dampak yang sangat besar dalam berbagai aktivitas masyarakat Indonesia. Dunia pendidikan merupakan salah satu bidang yang terkena dampak pasca dikeluarkannya peraturan tersebut. Sekolah atau Perguruan Tinggi harus menghentikan pertemuan secara langsung dan bergerak melalui jaringan (online). Dunia pendidikan memiliki taruhan jangka panjang, yang akan berpengaruh terhadap kelangsungan sumberdaya manusia dan masa depan Indonesia sendiri (Solihin, 2020). Implementasi pembelajaran daring di Indonesia pada dasarnya bukan merupakan suatu hal yang baru. Pembelajaran daring mulai dikembangkan di negara ini tahun 1980an, hanya saja belum mencakup seluruh jenjang Pendidikan (Kelana et al., 2021). Belajar online dapat dilakukan dengan memanfaatkan teknologi informasi dan komunikasi, seperti media komputer dengan berbantuan jaringan internet, telepon maupun fax (Siregar, Eko Febri Syahputra; Damailia, 2020).

Kondisi ini menimbulkan permasalahan, salah satunya Perguruan Tinggi. Perguruan Tinggi harus fokus menemukan solusi pelaksanaan perkuliahan yang efektif melalui jaringan agar mahasiswa tetap memperoleh perkuliahan. Untuk siswa yang belajar dari jarak jauh, tutorial online memiliki potensi untuk mempertemukan siswa dengan minat belajar yang sama dan membangun jaringan hubungan untuk menciptakan komunitas praktik (Lave \& Wenger, 1990)(Chandler, 2016). Perkuliahan online tergolong dalam dua aktivitas yaitu pembelajaran dan pertemuan. Pembelajaran dapat dilakukan tanpa adanya tatap muka antara dosen dan mahasiswa dengan memanfaatkan platform e-learning serta berbagai aplikasi lain seperti google classroom, Whatsapp, serta aplikasi moodle lainnya. Penggunaan aplikasi ini sangat membantu mahasiswa dalam belajar, menyimak, membaca dan mengirim tugas dari jarak jauh (Juliaster Marbun, 2021).

Terdapat beberapa metode pembelajaran yang dapat digunakan untuk meningkatkan konsentrasi belajar mahasiswa. Salah satu metode pembelajaran tersebut adalah e-learning (Purba, 2019). Sedangkan pertemuan adalah perkuliahan yang terjadi dengan adanya pertemuan secara langsung melalui aplikasi dengan lokasi atau tempat yang berbeda antara dosen dan mahasiswa. Aplikasi yang sering digunakan untuk mendukung pertemuan online, diantaranya Zoom, Google Meet, Microsoft Teams, Skype dan lain sebagainya.

Meskipun perkuliahan berlangsung secara online, namun harus tetap merujuk pada Capaian Pembelajaran Mata Kuliah (CPMK) pada setiap mata kuliah yang telah disusun. Kelebihan pembelajaran daring dibandingkan pembelajaran luring ialah: 1) aksesibilitas lebih luas; 2) proses pembelajaran dapat belangsung lebih cepat; 3) membangun lingkungan belajar yang kolaboratif dan eksploratif; 4) menghemat waktu dan biaya; 5) akses dapat dikontrol; dan 6) dapat mengakses langsung ke banyak sumber. Disisi lain kekurangannya yaitu: 1) harus tersedia akses server web atau internet yang memadai; 2) perlu waktu untuk mempersiapkan aplikasi pendukung; 3) penilaian dan umpan balik siswa terbatas; dan 4) perlu sumber daya yang menguasai internet (Radovi, 2010). Keterampilan-keterampilan penting di abad ke-21 masih relevan dengan empat pilar kehidupan yang mencakup learning to know, learning to do, learning to be dan learning to live together (Nurulaen, 2011). Keterampilan abad 21 merupakan target utama perkuliahan agar mahasiswa tidak berkembang dari ranah kognitif saja, melainkan diimbangi dengan ranah afektif dan psikomotorik. Menurut Bloom ada tiga domain belajar, yaitu kognitif, afektif, dan psikomotorik (Sari, Suci Perwita; Siregar, 2020). Kemampuan tersebut diatandai dengan keterampilan berpikir kritis, kemampuan berkomunikasi secara efektif, berinovasi dan memecahkan masalah melalui negosiasi dan kolaborasi. Kemampuan inilah yang saat ini dikenal dengan Keterampilan abad 21 (Siregar \& Suci Perwita Sari, 2020). Keterampilan berpikir kritis (Critical thinking), Kolaborasi (Colaboration), Kerjasama (Cooperatif) dan Kreativitas (Creativity) merupakan bagian dari keterampilan abad 21 atau yang lebih sering dikenal dengan 4Cs. Di sekolah formal, pembelajaran sudah dituntut untuk menerapkan kemampuan 4C (Critical Thinking, Communiaction, Collaboration, Creativity), ini dapat terwujud cepat tidak hanya tuntutan pada kinerja guru dalam mengubah 
4162 Pengaruh Breakout Room Aplikasi Zoom terhadap Kemampuan Berpikir Kritis Mahasiswa PGSD pada Perkuliahan dalam Jaringan - Eko Febri Syahputra Siregar, Suci Perwita Sari, Baihaqi Siddik Lubis, Ismail Hanif Batubara

DOI: https://doi.org/10.31004/basicedu.v5i5.1479

metode mengajar, tetapi juga peran dan tanggung jawab pendidik non formal dalam membiasakan anak-anak menerapkan 4C dalam keseharian (Prihadi, 2017) (Sugiyarti et al., 2018). Kemampuan berpikir kritis menjadi penting untuk dikembangkan bagi peserta didik melalui proses pembelajaran (Affandy et al., 2019).

Pada LPTK, keempat keterampilan ini sangat penting untuk meningkatkan kualitas diri para mahasiswa calon guru. Mahasiswa harus menguasai keterampilan tersebut agar dapat menjadi fasilitator di dalam kelas masing-masing guna mengimplementasikan pendekatan Student Center Learning (SCL), karena didalam mengajar guru tidak sekedar memindahkan informasi yang mereka punya kepada peserta didik, namun juga melibatkan pengetahuan, membuat makna, mencari kejelasan, bersikap kritis dan membuat keputusan dengan demikian peserta didik akan mempunyai kemampuan berpikir yang baik dan mudah memahami serta mengingat konsep-konsep yang dipelajari (Arifah et al., 2018). Pembelajaran hendaknya memperhatikan kondisi individu anak karena merekalah yang akan belajar (Raehang, 2014). Berpikir kritis merupakan kemampuan seseorang dalam mengambil keputusan, dan menganalisis masalah serta mampu mengatasi masalah yang dihadapinya sesuai dengan keputusan yang sudah ia yakini dan percaya (Walfajri \& Harjono, 2019) (Handayani et al., 2021).

Berdasarkan pengalaman yang diperoleh peneliti pada perkuliahan online di prodi PGSD FKIP UMSU, perkuliahan tersebut dilakukan dengan jenis kegiatan pertemuan. Aplikasi ataupun Platform yang digunakan adalah Zoom Meeting dengan tetap menggunakan e-learning universitas dan didukung dengan Whatsapp Group kelas sebagai ruang informasi. Selama perkuliahan berlangsung, peneliti belum melihat respon ataupun tanggapan yang diberikan mahasiswa terhadap penjelasan materi dari dosen. Mahasiswa masih menempatkan posisi sebagai pendengar selama perkuliahan berlangsung. Padahal sesungguhnya ada kesempatan yang diberikan bagi mahasiswa untuk memberikan tanggapan terhadap materi yang menjadi pembahasan. Namun para mahasiswa tidak memanfaatkan hal tersebut dan hanya diam dan selalu mematikan microphone pada aplikasi zoom masing-masing. Salah satu aplikasi yang menyediakan fasilitas interaksi tatap muka antara dosen dan mahasiswa secara virtual melalui video conference dengan PC atau laptop atau smartphone adalah zoom cloud meeting (Sasomo, 2021). Begitu juga ketika presentasi dilakukan salah satu kelompok yang terdapat di kelas, mahasiswa yang lain hanya mendengarkan dan ketika ada yang bertanya, pertanyaan yang diajukan hanya pertanyaan yang mengarah pada keterampilan bertanya tingkat rendah atau dikenal dengan Lower Order Thinking Skill (LOTS).

Menyikapi peristiwa di atas, diperlukan adanya tindakan yang sangat tepat untuk mengatasi permasalahan tersebut. Perubahan metode pembelajaran yang dilakukan melalui pembelajaran tatap muka menjadi daring yang dilakukan secara tiba- tiba berdampak pada kesehatan mahasiswa, baik secara fisik maupun mental (Pustikasari \& Fitriyanti, 2021). Mahasiswa sebagai agen of change harus mampu berpikir kritis pada setiap keadaan. Sebagai pemegang tonggak kehidupan di masa depan, mahasiswa harus aktif dan tidak dapat sekedar diam saja. Tanggapan maupun pendapat mahasiswa sangat dibutuhkan sebagai kaum intelektual dan generasi milenial bangsa ini. Sehingga para mahasiswa tidak hanya menerima saja namun harus memberikan umpan balik untuk perbaikan kedepannya. Solusi yang dapat dilakukan untuk menimbulkan keterampilan berpikir kritis mahasiswa adalah dengan pemanfaatan fitur pendukung pada aplikasi Zoom, yaitu Breakout Room. Zoom bisa dikatergorikan bagaikan media pendidikan online yang bisa dimaksud bagaikan sesuatu tipe belajar mengajar yang membolehkan tersampaikannya bahan ajar ke siswa dengan memakai media Internet (Zhang, Chen, $\mathrm{Ng}$, \& Koltun, 2019) dalam (Dedi Robandi, Darmansyah, Fetri Yeni, 2017). Dalam aplikasi Zoom Meeting ini kita bisa berkomunikasi (Haqien \& Rahman, 2020). Fitur breakoutrom akan menempatkan mahasiswa sesuai kelompok yang telah dibagi oleh dosen. Pada awalnya, mahasiswa masih berada pada kelas besar (klasikal), kemudian setelah dibagi menjadi beberapa kelompok, mahasiswa akan dipindahkan ke ruangan kelompok oleh dosen atau host kelas tersebut. Pada Zoom Breakout Room siswa diberikan kelonggaran untuk berkomunikasi dalam bahasa lisan dengan kelompoknya dalam 
4163 Pengaruh Breakout Room Aplikasi Zoom terhadap Kemampuan Berpikir Kritis Mahasiswa PGSD pada Perkuliahan dalam Jaringan - Eko Febri Syahputra Siregar, Suci Perwita Sari, Baihaqi Siddik Lubis, Ismail Hanif Batubara

DOI: https://doi.org/10.31004/basicedu.v5i5.1479

memecahkan masalah yang diberikan oleh guru, yaitu sebelum diadakan diskusi guru menggunakan Zoom Breakout Room untuk secara otomatis menentukan anggota setiap kelompok (Putrah, 2020). Durasi waktu selama berada di ruangan tersebut dapat dibatasi sesuai dengan yang telah disepakati. Sehingga melalui fitur ini diharapkan dapat membiasakan mahasiswa berpikir kritis dengan keterbatas waktu yang dimiliki. Aplikasi ini tidak hanya digunakan untuk pembelajaran saja tetapi bisa digunakan untuk urusan perkantoran maupun urusan lainnya (Hamid, 2020). Seperti penelitian yang dilakukan oleh (Annisa Purnamasari, 2020) diperoleh hasil bahwa platform Zoom fitur Breakout room dapat meningkatkan kemampuan berpikir kritis peserta didik. Hal itu terlihat dari hasil tes kemampuan pada siklus I, nilai rata-rata kelas mencapai 76,3, kemudian pada siklus II mengalami peningkatan yaitu 83,5 dan Ketika siklus III sudah naik menjadi 85,7. Pembelajaran yang idealnya memiliki interaktifitas antara pendidik dan peserta didik walaupun tidak dalam satu tempat yang sama, dengan adanya video conference akan membantu proses pembelajaran yang dilakukan, karena pendidik akan terlibat langsung dengan peserta didik (Sandiwarno, 2016) (Monica \& Fitriawati, 2020).

Berdasarkan penelitian tersebut, maka peneliti tertarik untuk melihat apakah terdapat pengaruh Platform Breakout Room pada Zoom dalam mendukung perkuliahan di prodi PGSD FKIP UMSU, sehingga penelitian ini berjudul Pengaruh Breakout Room Aplikasi Zoom Terhadap Kemampuan Berpikir Kritis Mahasiswa PGSD pada Perkuliahan Dalam Jaringan.

\section{METODE}

Penelitian ini dilakukan di Program studi PGSD FKIP UMSU yang beralamat di Jalan Kapten Muchtar Basri Kelurahan Glugur Darat II Kecamatan Medan Timur Kota Medan. Jenis penelitian yang digunakan yaitu pre-experimental design dengan desain penelitian the one shoot case study. Sugiyono (2012: 109) mengelompokkan tiga jenis desain penelitian yang lazim digunakan pada metode pre-experimental design, yakni one-shot case study, one-group, pretest-posttest design, dan intact-group comparison.

Adapun populasi pada penelitian ini adalah mahasiswa semester dua Program studi PGSD yang berjumlah 45 orang. Menurut Subagyo (1991: 23), "Populasi merupakan obyek penelitian sebagai sasaran untuk mendapatkan dan mengumpulkan data", sedangkan sampel adalah bagian dari populasi yang dianggap mewakili untuk dijadikan sumber data. Teknik penentuan sampel pada penelitian ini menggunakan teknik simple random sampling dengan setiap elemen yang dijadikan sampel, diambil dengan teknik pengambilan secara acak (random) dari populasi. Teknik ini dipakai karena populasi dalam penelitian ini bersifat homogen. Sampel dalam penelitian ini adalah 30 karakteristik keterampilan berpikir kritis mahasiswa PGSD.

Teknik pengumpulan data yang digunakan pada penelitian ini yaitu menggunakan tes dan non tes. Tes yang digunakan yaitu berupa pertanyaan uraian, sedangkan non tes yaitu melalui angket. Bentuk tes hasil belajar yang digunakan adalah tes uraian dengan jumlah 4 (empat) soal. Tes hasil belajar dirancang sedemikian rupa dengan berpedoman pada Taksonomi Bloom yang direvisi oleh Anderson. Adapun pertanyaan yang diberikan mencakup C3 (penerapan) dan C4 (analisis), C5 (evaluasi) dan C6 (kreasi). Sedangkan non tes yang digunakan adalah angket yang terdiri atas dua puluh pernyataan dengan tiap pernyataan memiliki empat pilihan, yaitu SS (Sangat Sering), S (Setuju), Ragu-Ragu (RR) dan TS (Tidak Setuju).

Teknik analisa data yang digunakan pada penelitian ini yaitu teknik statistik deskriptif dan inferensial yang digunakan untuk menguji hipotesis penelitian. Teknik inferensial yang digunakan adalah teknik analisis varians dua jalur dengan taraf signifikan 0,05. Sebelum teknik ini digunakan perlu dilakukan uji persyaratan. Uji persyaratan yang dilakukan adalah uji normalitas menggunakan liliefors (Sudjana, 2005:466) untuk mengetahui normal atau tidaknya sebaran data yang dianalisis. Sedangkan uji homogenitas menggunakan uji F, dan uji Bartlett (Sudjana, 2005:258). Kriteria pengujian adalah jika $F_{\text {hitung }}$ lebih kecil dari $F_{\text {tabel }}$ pada taraf 
4164 Pengaruh Breakout Room Aplikasi Zoom terhadap Kemampuan Berpikir Kritis Mahasiswa PGSD pada Perkuliahan dalam Jaringan - Eko Febri Syahputra Siregar, Suci Perwita Sari, Baihaqi Siddik Lubis, Ismail Hanif Batubara

DOI: https://doi.org/10.31004/basicedu.v5i5.1479

signifikan $5 \%$ maka data hasil penelitian ini adalah homogen. Kriteria pengujian hipotesis, yaitu $\mathrm{F}_{\text {hitung }}$ lebih besar dari $\mathrm{F}_{\text {tabel }}$ pada taraf signifikan $5 \%$ maka hipotesis yang diajukan diterima.

\section{HASIL DAN PEMBAHASAN}

Sebelum melakukan penelitian, Peneliti terlebih dahulu melakukan uji validitas kuesioner untuk megetahui apakah instrumen yang digunakan dapat mengukur hal yang ingin dicapai. Adapun mahasiswa yang menjadi objek pada penelitian ini adalah mahasiswa semester 2 kelas F sebanyak 30 orang mahasiswa. Adapun data yang diperoleh pada uji validitas dapat dilihat dibawah ini.

Tabel 1. Uji Validitas

\begin{tabular}{|c|c|c|c|c|}
\hline \multirow[b]{2}{*}{ No } & \multicolumn{4}{|c|}{ Uji Korelasi Product Moment } \\
\hline & $\begin{array}{c}\text { Kemampuan } \\
\text { berpikir kritis }\end{array}$ & $\mathbf{r}_{\text {tabel }}$ & $\mathbf{r}_{\text {hitung }}$ & Keterangan \\
\hline & $\begin{array}{l}\text { Saya membaca dengan teliti dalam menganalisa } \\
\text { pertanyaan/soal sebelum menyelesaikannya. }\end{array}$ & & 0,663 & Valid \\
\hline 2 & $\begin{array}{l}\text { Saya tidak berani memberikan kritik kepada orang lain } \\
\text { (teman apalagi Dosen) }\end{array}$ & & 0,445 & Valid \\
\hline 3 & $\begin{array}{l}\text { Saya mengemukakan pendapat secara runtut dari akar } \\
\text { masalah, gagasan penyelesaian sampai pada kesimpulan } \\
\text { jawaban }\end{array}$ & & 0,702 & Valid \\
\hline & $\begin{array}{l}\text { Saya langsung menyelesaikan pertanyaan/soal sesuai } \\
\text { dengan yang diarahkan. }\end{array}$ & & 0,658 & Valid \\
\hline 5 & $\begin{array}{l}\text { Apabila terdapat perbedaan pendapat dengan orang lain } \\
\text { ( baik Dosen maupun teman), saya tidak berani } \\
\text { mengevaluasi pendapat orang lain tersebut. }\end{array}$ & & 0,581 & Valid \\
\hline & $\begin{array}{l}\text { Saya suka mengarang jawaban jika menjawab } \\
\text { pertanyaan/soal }\end{array}$ & & 0,725 & Valid \\
\hline 7 & $\begin{array}{l}\text { Jika diberi tugas, saya akan melaksanakannya dengan } \\
\text { sebaik mungkin }\end{array}$ & & 0,637 & Valid \\
\hline 8 & $\begin{array}{l}\text { Saya tidak perlu mengevaluasi pendapat diri sendiri bila } \\
\text { terdapat perbedaan dengan pendapat orang lain }\end{array}$ & 0.396 & 0,611 & Valid \\
\hline & $\begin{array}{l}\text { Saya tidak mampu memahami materi yang dibahas } \\
\text { tanpa penjelasan dari Dosen }\end{array}$ & & 0,397 & Valid \\
\hline & $\begin{array}{l}\text { Saya akan melihat jawaban teman,jika saya sudah tidak } \\
\text { dapat menjawab pertanyaan/soal }\end{array}$ & & 0,533 & Valid \\
\hline & $\begin{array}{l}\text { Saya belajar tentang materi dengan membaca buku- } \\
\text { buku yang ada baik di perpustakaan maupun di internet. }\end{array}$ & & 0,639 & Valid \\
\hline & $\begin{array}{l}\text { Saya memiliki banyak ide dalam menyelesaikan } \\
\text { soal/pertanyaan yang diberikan. }\end{array}$ & & 0,566 & Valid \\
\hline & $\begin{array}{lccc}\text { Saya berperan akti dalam } & \text { menyelesaikan } \\
\text { soal/pertanyaan yang diberikan guru } & \\
\end{array}$ & & 0,581 & Valid \\
\hline & $\begin{array}{l}\text { Saya akan terus berusaha menyelesaikan } \\
\text { soal/pertanyaan yang sulit tanpa mengenal putus asa. }\end{array}$ & & 0,639 & Valid \\
\hline & $\begin{array}{l}\text { Saya hanya memiliki satu jawaban sesuai dengan yang } \\
\text { diajarkan oleh guru ketika menjawab pertanyaan }\end{array}$ & & 0,618 & Valid \\
\hline & $\begin{array}{l}\text { Saya mengerjakan soal/pertanyaan yang diajukan } \\
\text { dengan terperinci }\end{array}$ & & 0,515 & Valid \\
\hline
\end{tabular}


4165 Pengaruh Breakout Room Aplikasi Zoom terhadap Kemampuan Berpikir Kritis Mahasiswa PGSD pada Perkuliahan dalam Jaringan - Eko Febri Syahputra Siregar, Suci Perwita Sari, Baihaqi Siddik Lubis, Ismail Hanif Batubara

DOI: https://doi.org/10.31004/basicedu.v5i5.1479

\begin{tabular}{|c|c|c|c|}
\hline & $\begin{array}{l}\text { Saya berani mengemukakan gagasan yang saya peroleh } \\
\text { untuk menyelesaikan soal }\end{array}$ & 0,621 & Valid \\
\hline & $\begin{array}{l}\text { Saya dapat meneruskan cara menyelesaikan masalah } \\
\text { soal yang berbeda dengan orang lain }\end{array}$ & 0,661 & Valid \\
\hline 19 & $\begin{array}{l}\text { Saya tidak malu bertanya kepada orang lain bila sedang } \\
\text { mendapatkan kesulitan. }\end{array}$ & 0,567 & Valid \\
\hline 20 & Saya mau mendengarkan kritik dan saran dari orang lain & 0,614 & Valid \\
\hline 21 & Saya berbicara dengan dengan kata-kata yang jelas. & 0,621 & Valid \\
\hline & $\begin{array}{l}\text { Saya membuat orang lain bingung dengan apa yang } \\
\text { saya bicarakan. }\end{array}$ & 0,573 & Valid \\
\hline & $\begin{array}{l}\text { Saya berani memberikan masukan dalam diskusi } \\
\text { kelompok. }\end{array}$ & 0,654 & Valid \\
\hline 24 & $\begin{array}{l}\text { Saya mengandalkan orang lain untuk mengerjakan, } \\
\text { ketika diberi tugas oleh kelompok. }\end{array}$ & 0,514 & Valid \\
\hline & $\begin{array}{l}\text { Saya tidak memberikan jawaban ketika teman mau } \\
\text { mencontek }\end{array}$ & 0,511 & Valid \\
\hline
\end{tabular}

Berdasarkan tabel di atas, maka dapat disimpulkan yaitu dari dua puluh lima pernyataan yang terdapat dalam angket diperoleh nilai $\mathbf{r}_{\text {tabel }}$ sebesar 0,396 dan keseluruhan pernyataan dikatakan valid dengan nilai tertinggi yaitu 0,725 pada pernyataan nomor enam dan nilai terendah yaitu 0,397 pada pernyataan nomor 9 . Maka dari itu keseluruhan pernyataan ini selanjutnya dapat digunakan sebagai alat ukur (instrumen) untuk mengetahui kemampuan berpikir kritis mahasiswa.

Setelah dilakukan uji validitas, maka langkah selanjutnya adalah mengukur reabilitas (tingkat kepercayaan) tes yang hendak digunakan. Berdasarkan hasil uji reabilitas pada palikasi SPSS 22 diperoleh hasil yaitu 0,923 dan dapat dilihat pada tabel berikut.

Tabel 2. Uji Realibilitas

Reliability Statistics

Cronbach's

Alpha $\quad \mathrm{N}$ of Items

, $923 \quad 25$

Setelah hasil uji reabilitas diperoleh, kemudian peneliti melakukan uji normalitas data hasil penelitian untuk mengetahui apakah data berdistribusi normal atau tidak normal. Berdasarkan hasil uji validitas pada data hasil penelitian ini, diperoleh hasil sebagai berikut :

Tabel 3. Uji Normalitas Data

\begin{tabular}{llr}
\hline \multicolumn{3}{c}{ One-Sample Kolmogorov-Smirnov Test } \\
\hline & & $\begin{array}{r}\text { Critical_thinkin } \\
\text { g_skill }\end{array}$ \\
\hline $\mathrm{N}$ & & 45 \\
\hline Normal Parameters ${ }^{\mathrm{a}, \mathrm{b}}$ & Mean & 78,00 \\
\cline { 2 - 3 } & Std. Deviation & 6,941 \\
\hline Most Extreme Differences & Absolute &, 169 \\
\cline { 2 - 3 } & Positive &, 112 \\
\cline { 2 - 3 } & Negative &,- 169 \\
\hline
\end{tabular}


4166 Pengaruh Breakout Room Aplikasi Zoom terhadap Kemampuan Berpikir Kritis Mahasiswa PGSD pada Perkuliahan dalam Jaringan - Eko Febri Syahputra Siregar, Suci Perwita Sari, Baihaqi Siddik Lubis, Ismail Hanif Batubara

DOI: https://doi.org/10.31004/basicedu.v5i5.1479

\begin{tabular}{lrr}
\hline Test Statistic &, 169 \\
\hline Asymp. Sig. (2-tailed) &, $002^{\mathrm{c}}$ \\
\hline Monte Carlo Sig. (2-tailed) Sig. &, $134^{\mathrm{d}}$ \\
\cline { 2 - 3 } & $99 \%$ Confidence Interval & Lower Bound \\
\cline { 2 - 3 } & Upper Bound &, 126 \\
\hline a. Test distribution is Normal. & \\
\hline b. Calculated from data. & \\
\hline c. Lilliefors Significance Correction. & \\
\hline d. Based on 10000 sampled tables with starting seed 2000000. & \\
\hline
\end{tabular}

Berdasarkan data uji normalitas diatas, maka dapat disimpulkan bahwa data hasil penelitian ini berdistribusi normal dengan perolehan nilai uji normalitas menggunakan monte carlo sebesar 0,134>0,05 dengan taraf signifikansi 0,05 .

Langkah akhir setelah diperoleh data dengan distribusi normal yaitu melakukan uji hipotesisi penelitian. Adapun uji hipotesis penelitian meggunakan one sample $t$ test. Data peroleh uji hipotesis dapat dilihat pada tabel berikut :

Tabel 4

\begin{tabular}{|c|c|c|c|c|c|c|}
\hline \multicolumn{7}{|c|}{ One-Sample Test } \\
\hline & \multicolumn{6}{|c|}{ Test Value $=0$} \\
\hline & \multirow[b]{2}{*}{$\mathrm{t}$} & \multirow[b]{2}{*}{ df } & \multirow{2}{*}{$\begin{array}{l}\text { Sig. (2- } \\
\text { tailed) }\end{array}$} & \multirow{2}{*}{$\begin{array}{c}\text { Mean } \\
\text { Difference }\end{array}$} & \multicolumn{2}{|c|}{$\begin{array}{l}\text { 95\% Confidence } \\
\text { Interval of the } \\
\text { Difference }\end{array}$} \\
\hline & & & & & Lower & Upper \\
\hline CTS & 148,702 & 44 & , 000 & 8,82299 & 8,7034 & 8,9426 \\
\hline
\end{tabular}

Berdasarkan tabel diatas, dapat disimpulkan bahwa uji one sample t test menunjukkan nilai sig. (2tailed) $0,000<0,05$ dengan taraf signifikan sebesar $0,05 \%$ sehingga dapat disimpulkan bahwa $\mathrm{H}_{0}$ ditolak dan $\mathrm{H}_{\mathrm{a}}$ diterima. Berdasarkan perolehan hasil uji t, maka dapat disimpulkan bahwa terdapat pengaruh Breakout Room Aplikasi Zoom terhadap kemampuan berpikir kritis mahasiswa PGSD pada mata kuliah Strategi Belajar Mengajar tahun akademik 2020/2021. Hal ini sejalan dengan penelitian (Kelana et al., 2021)yang memperoleh hasil bahwa selama masa pandemik COVID-19 aplikasi zoom meeting memiliki peranan yang sangat penting dalam pembelajaran sains terutama mengembangkan sikap-sikap ilmiah seperti mandiri, kreatif, disiplin, berpikir kritis, dan memiliki rasa ingin tahu yang tinggi.

\section{KESIMPULAN}

Adapun kesimpulan yang dapat diambil dari penelitian ini, yaitu penelitian ini telah mampu menjawab tujuan yang telah dirumuskan dengan hasil yang diperoleh yaitu terdapat pengaruh Breakout Room Aplikasi Zoom terhadap kemampuan berpikir kritis mahasiswa PGSD pada mata kuliah Strategi Belajar Mengajar tahun akademik 2020/2021 dengan hasil yang diperoleh melalui uji one sample $t$ test mendapatkan nilai sig. (2-tailed) $0,000<0,05$. 
4167 Pengaruh Breakout Room Aplikasi Zoom terhadap Kemampuan Berpikir Kritis Mahasiswa PGSD pada Perkuliahan dalam Jaringan - Eko Febri Syahputra Siregar, Suci Perwita Sari, Baihaqi Siddik Lubis, Ismail Hanif Batubara

DOI: https://doi.org/10.31004/basicedu.v5i5.1479

\section{DAFTAR PUSTAKA}

Annisa Purnamasari. (2020). Upaya Meningkatan Kemampuan Berpikir Kritis Siswa Dengan Model Problem Based Learning Dengan Platform Zoom Fitur Breakout Room Di Kelas Vii-A Smp Labschool Cibubur Annisa.

Arifah, U., Suyitno, H., \& Dewi, N. R. (2018). Kajian Teori: Meningkatkan Kemampuan Berpikir Kritis Matematis Melalui Model Brain Based Learning Berbantuan Powtoon. Prisma, Prosiding Seminar Nasional Matematika, 2, 718-723.

Chandler, K. (2016). Using Breakout Rooms In Synchronous Online Tutorials. Journal Of Perspectives In Applied Academic Practice, 4(3), 16-23. Https://Doi.Org/10.14297/Jpaap.V4i3.216

Dedi Robandi, Darmansyah, Fetri Yeni, J. (2017). Efektifitas Penggunaan Aplikasi Zoom Sebagai Media Pembelajaran Masa Pandemi Covid-19 Di Kampus Ipdn Sumatera Barat. Ejtech, 00(00), Xx-Xx. Https://Doi.Org/10.1007/Xxxxxx-Xx-0000-00

Hamid, A. (2020). Pemanfaatan Aplikasi Zoom Meeting Dalam Proses Pembelajaran Di Masa Pandemi Covid-19 Pada Mahasiswa Jurusan Pendidikan Ips Fkip Universitas Tadulako. Jurnal Pendidikan Ilmu Sosial, 17(2), 166-174.

Handayani, S. L., Budiarti, I. G., Kusmajid, K., \& Khairil, K. (2021). Problem Based Instruction Berbantuan E-Learning: Pengaruhnya Terhadap Kemampuan Berpikir Kritis Peserta Didik Sekolah Dasar. Jurnal Basicedu, 5(2), 697-705. Https://Doi.Org/10.31004/Basicedu.V5i2.795

Haqien, D., \& Rahman, A. A. (2020). Use Of Zoom Meetings For The Learning Process During The Covid19 Pandemic. Sap (Susunan Artikel Pendidikan), 5(1).

Juliaster Marbun, S. J. S. (2021). Pemanfaatan Aplikasi Google Classroom Dalam Meningkatkan Efektivitas Belajar Mahasiswa Berbasis Daring Di Masa Pandemik Covid-19. Jurnal Basicedu, 5(5), 3299-3305.

Kelana, J. B., Wulandari, M. A., \& Wardani, D. S. (2021). Penggunaan Aplikasi Zoom Meeting Di Masa Pandemi Covid-19. Jurnal Elementary, 4(1), 18-22.

Monica, J., \& Fitriawati, D. (2020). Efektivitas Penggunaan Aplikasi Zoom Sebagai Media Pembelajaran Online Pada Mahasiswa Saat Pandemi Covid-19. Jurnal Communio : Jurnal Jurusan Ilmu Komunikasi, 9(2), 1630-1640. Https://Doi.Org/10.35508/Jikom.V9i2.2416

Nurulaen, Y. (2011). Keterampilan Abad Ke-21: Keterampilan Yang Diajarkan Melalui Pembelajaran. Jurnal Penelitian Pendidikan, Edisi Khus(2), 154-163.

Purba, L. S. L. (2019). Peningkatan Konsentrasi Belajar Mahasiswa Melalui Pemanfaatan Evaluasi Pembelajaran Quizizz Pada Mata Kuliah Kimia Fisika I. Jurnal Dinamika Pendidikan, 12(1), 29. Https://Doi.Org/10.33541/Jdp.V12i1.1028

Pustikasari, A., \& Fitriyanti, L. (2021). Stress Dan Zoom Fatigue Pada Mahasiswa Selama Pembelajaran Daring Di Masa Pandemi Covid-19. Jurnal Ilmiah Kesehatan, 13(1), 25-37. Https://Doi.Org/10.37012/Jik.V13i1.467

Radovi, M. (2010). Advantages And Disadvantages Of E-Learning In Comparison To Traditional Forms Of Learning. Annals Of The University Of Petrosani : Economics, 10(2), 289-298.

Raehang. (2014). Pembelajaran Aktif Sebagai Induk Pembelajaran Kooperatif. Jurnal Al-Ta'dib, 7(1), 149167. Ejournal.Iainkendari.Ac.Id/Al-Tadib/Article/View/249/239

Sari, Suci Perwita; Siregar, E. F. S. (2020). Pengaruh Model Pembelajaran Abad 21 4cs Dalam Meningkatkan Keterampilan Membuat Pertanyaan Tingkat Tinggi Mahasiswa Pgsd Fkip Pada Materi Gejala Alam T.A. 2019/2020. Jurnal Ilmiah Aquinas, 3(2), 208-215.

Sasomo, B. (2021). Pengembangan Pembelajaran Student Teams Achievement Divisions (Stad)- Virtual Melalui Breakout Room Pada Aplikasi Zoom Meeting. Phytagoras: Jurnal Program Studi Pendidikan 
4168 Pengaruh Breakout Room Aplikasi Zoom terhadap Kemampuan Berpikir Kritis Mahasiswa PGSD pada Perkuliahan dalam Jaringan - Eko Febri Syahputra Siregar, Suci Perwita Sari, Baihaqi Siddik Lubis, Ismail Hanif Batubara

DOI: https://doi.org/10.31004/basicedu.v5i5.1479

Matematika, 10(April).

Siregar, Eko Febri Syahputra; Damailia, E. (2020). Pembelajaran Online Sebagai Bentuk Penguatan Pendidikan Selama Pandemi Covid-19 Di Sd Muhammadiyah 03 Kota Medan. Jurnal Ilmiah Aquinas, $\operatorname{Iii}(2), 306-315$.

Siregar, E. F. S., \& Suci Perwita Sari. (2020). Optimalisasi Pendekatan Mikir Sebagai Solusi Pembelajaran Abad 21 Bagi Guru Sd Muhammadiyah Kota Medan. Dinamisia: Jurnal Pengabdian Kepada Masyarakat, 4(3), 550-556. Https://Doi.Org/10.31849/Dinamisia.V4i3.4376

Solihin, A. (2020). Pembelajaran Online Dengan Aplikasi Zoom Meeting. 3(2), 17-23.

Sugiyarti, L., Arif, A., \& Mursalin. (2018). Pembelajaran Abad 21 Di Sd. Prosiding Seminar Dan Diskusi Nasional Pendidikan Dasar, 439-444. 